\title{
Olga BOGORODECKA
}

Wschodnioeuropejski Uniwersytet Narodowy im. Łesi Ukrainki, Łuck, Ukraina

\section{Cechy charakterystyczne rozwoju współpracy miast bliźniaczych Polski i Ukrainy}

\author{
The Peculiarities of Poland and Ukraine's Twin Cities' Cooperation Progress
}

\begin{abstract}
The aim of the research carried out within the framework of the present article is a detailed analysis of the origin, formation, and development of Poland and Ukraine's twin cities' compounds. The main attention will be focused on the historical aspects of identification of Ukrainian and Polish town twinning cooperation development. An important part of this work will cover the determination of the spatial aspects of Ukraine and Poland twin cities' development cooperation.
\end{abstract}

Keywords: twin cities, cooperation, Poland, Ukraine

Słowa kluczowe: miasta bliźniacze, współpraca, Polska, Ukraina

\section{Wprowadzenie}

Związkibliźniacze miastsąjednązważniejszych formwspółpracymiędzynarodowej. Dziś obok państw w stosunki międzynarodowe wstępują jednostki terenowe. Kształtowanie związków bliźniaczych to skomplikowany i wielotorowy proces, który wymaga obecności reguł, bez których ich istnienie byłoby niemożliwe. Miasta, które są bliźniaczymi, otrzymują szerokie perspektywy wymiany doświadczeń, rozwiązywania problemów, otrzymania pomocy, a także możliwości wspólnej i efektywnej realizacji projektów i inicjatyw. Współpraca miast bliźniaczych staje się bardzo istotnym instrumentem zewnętrznych związków państwa.

Krajem, gdzie znajduje się najwięcej miast bliźniaczych Ukrainy, jest Polska. Jest to bardzo ważny partner i czołowy „adwokat” Ukrainy na arenie europejskiej. Z tego powodu badanie stosunków polsko-ukraińskich jest niezwykle istotne. Doświadczenie Polski w zakresie dyplomacji publicznej ma zasadnicze znaczenie dla rozwoju społeczeństwa obywatelskiego na Ukrainie, co skutkuje oddolnym wzmocnieniem demokracji. 


\section{Podstawy teoretyczne}

Miasta bliźniacze to dwa miasta położone w różnych państwach, między którymi na podstawie podpisanych umów są ustalone stałe partnerskie związki polegające na: zapoznaniu się z życiem, historią i kulturą, osiągnięciu większego porozumienia, umacnianiu współpracy i przyjaźni między narodami oraz wymianie doświadczeń ${ }^{1}$. W zależności od treści, umowa włącza punkty o rozwoju współpracy kulturalnej, socjalnej, ekonomicznej, sportowej i innej.

Pojęcie „współpracy bliźniaczej” w literaturze publicystycznej (na łamach gazet i czasopism krajów Unii Europejskiej i Stanów Zjednoczonych) określane jest terminem twinning. Utworzona w 1951 roku Rada Gmin Europy (tak wówczas brzmiała nazwa CEMR) chętnie poparła tę ideę. To gminy miały wziąć na siebie budowę nowej Europy. Spontanicznemu ruchowi nadano nazwę związków bliźniaczych. Rozwijał się on równolegle z procesem jednoczenia Europy - wówczas tylko jej zachodniej części. Lata pięćdziesiąte przyniosły prawdziwą eksplozję liczby partnerstw. Jane Beret, współzałożyciel Rady Gmin i Regionów Europy (CEMR) po drugiej wojnie światowej wprowadził pojęcie twinning jako współpracę między dwoma społecznościami, które starają się działać w sposób efektywny by rozwiązywać istniejące problemy oraz tworzyć przyjazne stosunki².

Głównymi wartościami współpracy miast bliźniaczych są przyjaźń, współpraca, wzajemne wsparcie narodów Europy. Twinning to niezwykle elastyczny instrument, ponieważ, taką współpracę mogą nawiązać wioski, miasteczka i duże miasta, gminy, województwa. Istnienie powiązań bliźniaczych daje możliwość wymiany doświadczeń i pomysłów. Powiązania te przewidują długoterminowe zobowiązania partnerów, i nie mają charakteru krótkoterminowych partnerskich projektów. Należy zauważyć, że twinning zazwyczaj jest w stanie przetrwać zmiany politycznych liderów i tymczasowe trudności jednego z partnerów. Nosząc długoterminowy charakter, niezwykle ważnie jest regularne odnawianie porozumień, by odpowiadały potrzebom teraźniejszości. Twinning nie może się rozwijać bez aktywnego udziału obywateli. Właśnie w tym celu tworzą się komitety współpracy miast bliźniaczych, złożone z przedstawicieli miejscowej władzy i mieszkańców miast.

Należy zaznaczyć, że w Stanach Zjednoczonych, miasta bliźniacze przyjęto nazywać sister-cities, czyli miasta siostrzane. Innym określeniem jest twin-cities (mia-

${ }^{1}$ Szerzej: About Sister Cities International, http://www.sister-cities.org/about-sister-cities-international.

${ }^{2}$ Szerzej: European Twinning, http://www.twinning.org/pl/page/historia-wsp\%C3\%B3\%C5\% 82pracy-partnerskiej.html. 
sta bliźniacze), które jest również szeroko używane. Miasta bliźniacze wewnątrz jednego państwa zdarzają się rzadko. W tym kontekście warto wspomnieć o przykładzie Niemiec, które były podzielone. Miasta NRD i RFN bywały bliźniaczymi i nawet po zjednoczeniu nie chciały zrezygnować z tego statusu; najbardziej znane przykłady to Chemnitz i Düsseldorf oraz Eisenhüttenstadt i Zarlui ${ }^{3}$.

Współpraca miast bliźniaczych we współczesnym rozumieniu rozwijała się także w latach drugiej wojny światowej. W tym okresie współpraca przyjęła charakter stosunków partnerskich. W 1942 roku, w jednym z najbardziej dramatycznych okresów wojny, w czasie bombardowań lotniczych przez wojska nazistowskie radzieckiego Stalingradu (obecnie Wołgograd), do mieszkańców i obrońców miasta został wystosowany telegram od mieszkańców angielskiego Coventry. Miasto to także ucierpiało wskutek bombardowań faszystowskich. Anglicy wyrazili w nim swój zachwyt nad odwagą mieszkańców Stalingradu i zaproponowali ustanowienie stosunków przyjacielskich. W wyniku tych ustaleń podpisano umowę o przyjaźni i współpracy między miastami i w ten sposób stały się bliźniaczymi ${ }^{4}$.

Po zakończeniu wojny byli oponenci poparli ideę wznowienia relacji międzynarodowych (w tym i współpracy między miastami bliźniaczymi) jako sposobu osiągnięcia porozumienia i zapobieżenia nowym konfliktom. Tylko przez dwa lata po zakończeniu działań wojennych między Wielką Brytanią i Niemcami Brystol i Hanower zostały bliźniaczymi. Skutkowało to wysyłką do Hanoweru żywności i odzieży, oraz organizacją edukacyjnych wymian. Aktualnie liczba mieszkańców z obu miast uczestniczących w wymianach wynosi już ponad 25 tys. osób. Głównym celem współpracy bliźniaczej w tamtym czasie było naprawienie związków przyjacielskich bez względu na różnice społeczno-polityczne. Powstał rozwinięty i potężny ruch, który wniósł znaczący wkład w tworzenie dyplomacji miast i rozwoju miejskich związków międzynarodowych.

\section{Rozwój współpracy miast bliźniaczych Ukrainy i Polski}

Ukraińsko-polskie stosunki mają wielowiekową historię. W XXI wieku państwa otrzymały możliwość oparcia tych relacji o pokojowe i demokratyczne zasady. Współcześnie to właśnie na współpracy, a nie na wzajemnych oskarżeniach, można oprzeć rozwiązywanie problemów bezpieczeństwa międzynarodowego, likwi-

\footnotetext{
${ }^{3}$ С. Усанкова, Города-побратимь: для чего они нужныь?, http://shkolazhizni.ru/archive/0/ $\mathrm{n}-27140 /$.

${ }^{4}$ Szerzej: Б.В. Громов, Международное движение породненных городов и народная дипломаmия, Породненные города 2007, nr 1, s. 4.
} 
dację zagrożeń konfliktów zbrojnych i wyzwań ekologicznych. Ukraina i Polska, jako największe kraje Europy Środkowo-Wschodniej, mają wspólne doświadczenia w dziedzinie rozwoju władzy państwowej, samorządu terytorialnego, gospodarki, handlu, rozwiązania problemów paliwowo-surowcowych i ekologicznych, polityki zewnętrznej i obronnej. To wszystko sprzyja stworzeniu systemu efektywnego bezpieczeństwa, nauki, kultury, edukacji.

Stosunki ukraińsko-polskie wykraczają poza współpracę dwustronną, ponieważ łączy ich wspólna historia, kultura narodowa, stąd też łatwiej o ich zrozumienie i poszanowanie własnych interesów. Współpraca tych państw zauważalna jest na arenie międzynarodowej. Polska jako pierwsze państwo uznała niepodległość swojego sąsiada. Podpisano również konwencję konsularną między dwoma krajami. Po tych wydarzeniach w Warszawie i Kijowie rozpoczęli urzędowanie przedstawiciele dyplomatyczni w randze „specjalnych wysłanników rządów”. W dniu 4 stycznia 1992 r. ustalono stosunki dyplomatyczne. Warto zauważyć, że Polska już wcześniej miała w Kijowie swój Konsulat Generalny. W październiku 1991 r. Polska i Ukraina zawarły umowę o handlu i współpracy gospodarczej. Ponadto podpisana została Deklaracja o zasadach i podstawowych kierunkach rozwoju stosunków polsko-ukraińskich5. W dniu 18 maja 1992 r. zawarto Traktat o dobrym sqsiedztwie, przyjaznych stosunkach i wspótpracy. Ważnym dokumentem współpracy ukraińsko-polskiej jest Umowa między Rządem Ukrainy i Rządem Rzeczypospolitej Polskiej o wspótpracy międzyregionalnej, podpisana 24 maja 1993 roku. W niej potwierdzono prawne zasady współpracy samorządów Ukrainy i Polski na płaszczyźnie: ekonomicznej, kulturalnej, humanitarnej, edukacyjnej i turystycznej ${ }^{6}$.

Nawiązanie współpracy partnerskiej i bliźniaczej między miastami Ukrainy i Polski odbyło się jeszcze za czasów radzieckich. Należy zaznaczyć, że zawieranie umów miało wówczas charakter scentralizowany i nie zawsze inicjatywa pochodziła od obywateli miasta. W latach pięćdziesiątych i sześćdziesiątych rozpoczął się drugi etap rozwoju współpracy w ramach umocnienia związku ekonomicznego, wojskowego, politycznego między ZSRR i krajami demokracji ludowej. Podtrzymując proces pogłębiania związków rząd radziecki w 1956 r. przyjął decyzję, uzgodnioną z partiami komunistycznymi i rządami europejskich krajów socjalistycznych, o ustanowieniu przyjacielskich związków przygranicznych między obwodami ZSRR i województwami, okręgami, obwodami: Polski, Czechosłowacji, Węgier i Rumunii. Odpowiednie decyzje podjęły również władze regionów przy-

5 Szerzej: Посольство України в Республічі Польща /Договірно-правова база між Украӥною та Польщею, http://poland.mfa.gov.ua/ua/ukraine-pl/legal-acts, odczyt z 20.04.2012.

6 Угода між Урядом Украіни та Урядом Республіки Польща про міжрегіональне співробітництво, $24 \mathrm{~V}$ 1993, http://zakon2.rada.gov.ua/laws/show/616_171 
granicznych. Pierwsze kontakty przygraniczne ustanowiono w sierpniu 1956 r. między Lwowskim i Wołyńskim Komitetem Obwodowym Komunistycznej Partii Ukrainy i województwem lubelskim oraz między komitetami partyjnymi tych obwodów i województw. W 1959 r. do współpracy przygranicznej dołączają również miasta i rejony?

Rozszerzenie i pogłębienie związków na poziomie rejonów i miast stwarzało pozytywne warunki dla kontaktów między zespołami przedsiębiorstw tej samej branży, a także pracownikami gospodarki rolnej. Należy zauważyć, że ustanawiano także kontakty kulturalne między związkami twórczymi, zespołami artystycznymi, teatrami dramatycznymi, domami kultury i szkołami muzycznymi. Współpraca miast bliźniaczych stanowiła jeden z ważniejszych komponentów rozwoju współpracy międzypaństwowej i była podstawą „przyjaźni” między Związkiem Radzieckim i europejskimi krajami socjalistycznymi.

Lata sześćdziesiąte charakteryzują się wzmacnianiem kontaktów międzypaństwowych i poprawą ich form, były także jakościowo nowym etapem w rozwoju współpracy miast bliźniaczych Związku Radzieckiego z miastami innych krajów. W 1964 r. w Związku Radzieckim stworzono organizację, kierującą miastami bliźniaczymi: Sojusz Związku Radzieckiego z Miastami Obcych Państw. Przez partnerstwo setek miast Rosji i innych republik Związku Radzieckiego z miastami innych państw wdrażano główny kierunek polityki zewnętrznej ZSRR: „ustalenia pokoju i przyjaźni między narodami”».

Do Światowej Organizacji Zjednoczonych Miast i Władz Lokalnych, Sojusz Związku Radzieckiego z Miastami Obcych Państw wszedł jako członek zespolony. Pomogło to około trzystu miastom byłego Związku Radzieckiego znaleźć swoich partnerów w 71 państwach świata. Jednym z pierwszych polskich miast, które ustanowiło związki bliźniacze z miastami Radzieckiej Ukrainy, był Koszalin. W 1958 r. zawarł umowę z Połtawąa . Głównymi obszarami współdziałania obu miast dotychczas zostają: kultura i wymiana doświadczeń.

Współpraca miast bliźniaczych Ukrainy i Polski rozwijała się aktywnie w czasach radzieckich. Łączyły się przeważnie główne miasta Ukrainy: Kijów, Charków, Odessa, Lwów i Polski: Warszawa, Kraków, Poznań, Gdańsk. Inicjatywa takiej współpracy nie zawsze występowała od samych miast, a była podyktowana odgórnie. Praktycznie takie umowy pozostawały wyłącznie „umowami na pa-

7 В.П. Колесник, Интернациональнье связи трудящихся приграничньх областей СССР и европейских социалистических стран, Аьвов 1984, s. 18.

${ }^{8}$ Б. В. Громов, Международное движение породненных городов и народная дилломатия, ПороАненные города 2007, nr 1, s. 4-5, http://www.twin-cities.ru/texts/300-Gromov.pdf.

9 Полтавщина: Енщиклопедичний довідник, red. А. В. КуАрицького, Київ 1992, s. 556-557. 
pierze". Nowy etap współpracy miast bliźniaczych Polski i Ukrainy rozpoczął się po uzyskaniu niepodległości Ukrainy w 1991 r. Właśnie wówczas zawarto szereg umów o współpracy: Lwów-Rzeszów (1992); Kijów-Kraków (1993); Kijów-Warszawa (1994).

Charakteryzując okres współpracy miast bliźniaczych Ukrainy i Polski od 1991 r. do teraźniejszości, należy zaznaczyć, że największa jej aktywność przypadła na koniec lat dziewięćdziesiątych i początek dwutysięcznych. Ta aktywność jest związana z ogłoszeniem przez Ukrainę kursu na Europę (2002), co przyczyniło się do rozszerzenia kontaktów nie tylko na poziomie państwowym, lecz regionalnym i lokalnym.

Jak w przypadku każdego procesu związki miast bliźniaczych Ukrainy i Polski mają tendencje wzrostowe i spadkowe. Obecnie spada liczba podpisywanych umów o współpracy bliźniaczej, jednak praktyczny poziom zawartych wcześniej umów dynamicznie rośnie. Skomplikowane współczesne warunki, ekonomiczne kryzysy, rewolucje, sytuacje nadzwyczajne i wiele innych zjawisk jednoczą ludzi i skłaniają do bardziej efektywnego rozstrzygnięcia problemów i wymiany doświadczeń.

Najmniejsza ilość umów była zawarta w okresie lat 1991-1999, a największa w 2006 r. (15 umów). Była to odpowiedź na przyjętą przez Radę Najwyższą Ukrainy Odezwę z 20 czerwca 2002 r. do parlamentów, rządów i społeczeństw państw członkowskich Unii Europejskiej, w której zwrócono się z apelem o wspieranie dążeń państwa ukraińskiego do integracji europejskiej przez wyprowadzenie stosunków z Ukrainą na nowy poziom rozwoju, odpowiedni do zmian, jakie zaszły na kontynencie europejskim ${ }^{10}$.

Ustalenie i rozwój związków przyjacielskich między miastami w dużym stopniu zależy od działalności instytucji dyplomatycznych w obu krajach. Jednym z priorytetowych zadań ich działalności jest naprawienie dobrosąsiedzkich stosunków na różnych poziomach, w tym w obszarze związków miast partnerskich. Współcześnie w Polsce funkcjonuje 12 przedstawicielstw dyplomatycznych Ukrainy, na Ukrainie 8 przedstawicielstw dyplomatycznych Polski. Obecność znacznej liczby przedstawicielstw dyplomatycznych wskazuje na ścisłą współpracę między oboma państwami. Zabezpieczenie funkcjonowania szerokiej sieci konsulatów daje możliwość większego dostępu obywateli do informacji o sąsiednim kraju, jego kulturze, tradycjach i obyczajach, a także sprzyja przyjacielskim i ścisłym kontaktom między mieszkańcami miast. Właśnie te zasady leżą u podstaw współpracy miast bliźniaczych.

${ }^{10}$ Szerzej: Хронологія відносин Украйна - ЄC (інформаційна довідка), http://www.mfa.gov. $\mathrm{ua} / \mathrm{mfa} / \mathrm{en} / \mathrm{publication} /$ content/19084.htm, odczyt z 24.02.2013. 
Historia działalności instytucji dyplomatycznych Polski w Ukrainie sięga jeszcze początku lat dwudziestych XX wieku. Konsulat Rzeczypospolitej Polskiej w Charkowie został otwarty w 1994 r., kontynuując tradycje, stworzonego 1 marca 1924 r. Konsulatu Generalnego RP w Charkowie ${ }^{11}$. Historia Polskiej Misji Dyplomatycznej we Lwowie zaczęła się w 1987 r. jako Misja Konsularna, wtedy jeszcze Polskiej Rzeczpospolitej Ludowej. W 1993 r., już w wolnej Ukrainie, misja została przekształcona w Generalny Konsulat Rzeczypospolitej Polskiej. Pierwszym Konsulem Generalnym był Henryk Litwin, obecnie Nadzwyczajny i Pełnomocny Ambasador RP w Ukrainie ${ }^{12}$.

Tabela 1. Przedstawicielstwa dyplomatyczne Rzeczypospolitej Polskiej w Ukrainie

\begin{tabular}{|l|l|}
\hline Miasto & Rok założenia przedstawicielstwa \\
\hline Kijów & 1992 \\
\hline Lwów & 1993 \\
\hline Charków & 1994 \\
\hline Łuck & 2003 \\
\hline Odessa & 2003 \\
\hline Winnica & 2010 \\
\hline Żytomierz & 2010 \\
\hline Sewastopol & 2011 \\
\hline
\end{tabular}

Źródło: Opracowanie własne na podstawie Посольство Республіки Польща у Києвi, http://kijow. msz.gov.pl/uk/konsulski_ta_wizowi/wizowa_info/kons_okruhy/kons_okruhy, odczyt z 5.10.2013.

Tabela 2. Przedstawicielstwa dyplomatyczne Ukrainy w Rzeczypospolitej Polskiej

\begin{tabular}{|l|l|}
\hline Miasto & Rok założenia przedstawicielstwa \\
\hline Warszawa & 1992 \\
\hline Kraków & - \\
\hline Gdańsk & 1994 \\
\hline Wrocław & - \\
\hline Lublin & 2003 \\
\hline Rzeszów & 2003 \\
\hline
\end{tabular}

11 Szerzej: Ексклюзивне інтерв'ю з генеральним консулом Польщі в Харкові з питань вищої освimu, http://www.osvita.org.ua/abroad/articles/13.html, odczyt z 20.08.2013.

12 Polska placówka dyplomatyczna we Lwowie w latach 1987-2012, http://www.lwow.msz.gov. pl/pl/konsulat/konsulat_lwow, odczyt z 20.08.2013. 
Tab. $2-\mathrm{cd}$.

\begin{tabular}{|l|l|}
\hline Poznań & 2007 \\
\hline Chełm & - \\
\hline Szczecin & - \\
\hline Bydgoszcz & 2011 \\
\hline Przemyśl & 2012 \\
\hline Zielona Góra & - \\
\hline
\end{tabular}

Źródło: Opracowanie własne na podstawie: Офіційний сайт Міністерства закордонних справ України / Аипломатичні представництва за кордоном, http://mfa.gov.ua/ua/about-mfa/abroad/ honorary-consulates/92\#, odczyt z 14.08.2013.

Aktualnie Ukraina ma najbardziej rozwiniętą sieć kontaktów międzyregionalnych z Polską. Całe obwody Ukrainy i województwa Polski zawarły umowy o współpracy międzyregionalnej. Miasta każdego z województw Polski mają związki partnerskie i bliźniacze z miastami w Ukrainie. Na poziomach regionalnym i miejscowym między Ukrainą i Polską istnieje blisko 450 umów o współpracy partnerskiej w tym miast bliźniaczych 193 (stan na styczeń 2014).

Współpraca miast-bliźniaczych w Polsce (w porównaniu do innych krajów UE) polega na sprawnej działalności samorządów miejskich w zakresie promocji swoich miast. To doświadczenie jest w dużej mierze zasługą członkostwa Polski w UE, lecz w większym stopniu to wynik intensywnej pracy samorządów miejskich na rzecz rozwoju miast. Ważne jest to, że współpraca bliźniacza miast Polski realizuje się nie tylko w zakresie kultury, jak to jest właściwie w większości miast Ukrainy, ale i w branży ekonomicznej. Pozwala to gminom polepszyć perspektywy rozwoju, rozpocząć nowe inwestycje i stworzyć miejsca pracy. Dla Ukrainy doświadczenie współpracy bliźniaczej miast jest relatywnie nowe ale wciąż brakuje szczególnej strategii rozwoju. Ukraina ma wiele miast bliźniaczych na całym świecie ale strona praktyczna tej współpracy jest znikoma.

Należy zauważyć, że w ostatnich latach wizerunek Ukrainy jako pewnego partnera istotnie się zmienił. Wojny gazowe z Federacją Rosyjską, polityczne zatargi w kraju, brak spójnej polityki zewnętrznej osłabiły rozwój związków zewnętrznych miast Ukrainy. Intensywność zawierania umów o współpracy miast bliźniaczych Ukrainy i Polski obecnie znacznie się obniżyła. 


\section{Cechy przestrzenne rozwoju współpracy miast bliźniaczych Ukrainy i Polski}

Wśród 24 obwodów w Ukrainie współpracę bliźniaczą prowadzą 23. Najbardziej aktywnymi regionami Ukrainy są obwody: winnicki (10 miast ma związki z miastami bliźniaczymi w Polsce); lwowski (10); iwanofrankowski (7) i rówieński (7). W Polsce miasta wszystkich 16 województw współpracują z miastami Ukrainy. Miasta z województw: podkarpackiego, lubelskiego i świętokrzyskiego prowadzą z miastami Ukrainy najbardziej aktywną współpracę. Są to regiony znajdujące się najbliżej Ukrainy. Tamtejsze miasta łączy wspólna historia, tradycja kulturowa i - co niezwykle ważne - związki rodzinne.

Tabela 3. Udział województw we współpracy z miastami bliźniaczymi w Ukrainie

\begin{tabular}{|l|l|}
\hline Województwo w Polsce & $\begin{array}{l}\text { Liczba miast polskich województw, mających } \\
\text { związki bliźniacze z miastami w Ukrainie }\end{array}$ \\
\hline Podkarpackie & 31 \\
\hline Lubelskie & 20 \\
\hline Świętokrzyskie & 18 \\
\hline Małopolskie & 18 \\
\hline Śląskie & 17 \\
\hline Wielkopolskie & 13 \\
\hline Dolnośląskie & 12 \\
\hline Mazowieckie & 11 \\
\hline Łódzkie & 8 \\
\hline Pomorskie & 7 \\
\hline Warmińsko-mazurskie & 7 \\
\hline Opolskie & 7 \\
\hline Lubuskie & 4 \\
\hline Podlaskie & 4 \\
\hline Zachodniopomorskie & 4 \\
\hline Kujawsko-pomorskie & 3 \\
\hline
\end{tabular}

Źródło: opracowanie własne.

Cechą charakterystyczną związków bliźniaczych miast Polski i Ukrainy na terytoriach przygranicznych jest współpraca trangraniczna. Ma ona na celu podnoszenie poziomu jakości życia, pokonywanie podziałów ekonomicznych, popiera- 
nie idei jedności europejskiej i współdziałania międzynarodowego, przezwyciężanie negatywnych stereotypów etnicznych, umacnianie poczucia wspólnoty ${ }^{13}$. W ocenie władz polskich szczebla lokalnego najlepiej rozwija się współpraca kulturalna ${ }^{14}$. Przykładem wspólnej działalności jest projekt: Rozwój transgranicznego systemu zarządzania zagrożeniami naturalnymi na granicy polsko-ukraińskiej, zrealizowany przez Komendę Wojewódzką Państwowej Straży Pożarnej w Lublinie z Komendą Wojewódzką Państwowej Straży Pożarnej w Rzeszowie oraz Głównym Terytorialnym Zarządem Ministerstwa ds. Sytuacji Nadzwyczajnych w Obwodzie Lwowskim. W jego ramach zakupiono m.in. specjalistyczne samochody ratowniczo-gaśnicze oraz samochody ratownictwa wysokościowego. Jednym z elementów realizacji projektu były także wspólne ćwiczenia sprawdzające funkcjonowanie stałej platformy współpracy ds. wdrażania transgranicznego systemu zarządzania bezpieczeństwem publicznym. To pierwszy zakończony projekt w ramach Programu Współpracy Transgranicznej Polska-Białoruś-Ukraina (2007-2013) ${ }^{15}$.

Tabela 4. Najbardziej aktywne we współpracy bliźniaczej miasta Polski i Ukrainy

\begin{tabular}{|l|l|}
\hline Miasta Polski & Miasta Ukrainy \\
\hline Lublin & Iwano-Frankiwsk \\
\hline Kielce & Lwów \\
\hline Rybnik & Łuck \\
\hline Zielona Góra & Kowel \\
\hline Przemyśl & Truskawiec \\
\hline Rzeszów & Sambor \\
\hline Kraków & Kamieniec Podolski \\
\hline Łódź & Drohobycz \\
\hline Sanok & Tarnopol \\
\hline Jasło & Kałusz \\
\hline
\end{tabular}

Źródło: opracowanie własne.

13 Szerzej: G. Ślusarz, Potrzeby rozwoju współpracy transgranicznej, Rzeszów 2006, s. 11.

14 A. Kowalczyk, Problemy pogranicza polsko-ukrainskiego i rozwój współpracy transgranicznej, [w:] Pogranicze z Niemcami a inne pogranicza Polski, red. Z. Kurcz, Wrocław 1999, s. 209.

15 Program Wspótpracy Transgranicznej Polska-Białoruś-Ukraina 2007-2013, http://www.plby-ua.eu/pl,news,105, odczyt z 3.01.2013. 
Najwięcej aktywnych miast zostało skoncentrowanych w Ukrainie Zachodniej i w Polsce południowej (rycina nr 1). Chociaż w czasie ostatnich kilku lat widoczna jest tendencja zawierania umów o współpracy bliźniaczej między miastami Polski zachodniej i Ukrainy Wschodniej. Ważną rolę odgrywa tu Fundacja Współpracy Polsko-Ukraińskiej PAUCI, która powstała w kwietniu 2005 roku jako kontynuatorka Inicjatywy Współpracy Polsko-Amerykańsko-Ukraińskiej. Działając od 1999 roku służy jako wyjątkowy trójstronny program pomagający szerzyć najlepsze przykłady polskiej transformacji ustrojowej. Ponad 420 polskich i ukraińskich organizacji wspartych technicznie i finansowo przez PAUCI zrealizowało 188 projektów partnerskich mających zasadniczy wpływ na rozwój wolnego rynku i społeczeństwa obywatelskiego.

Rycina 1. Główne miasta bliźniacze Polski i Ukrainy

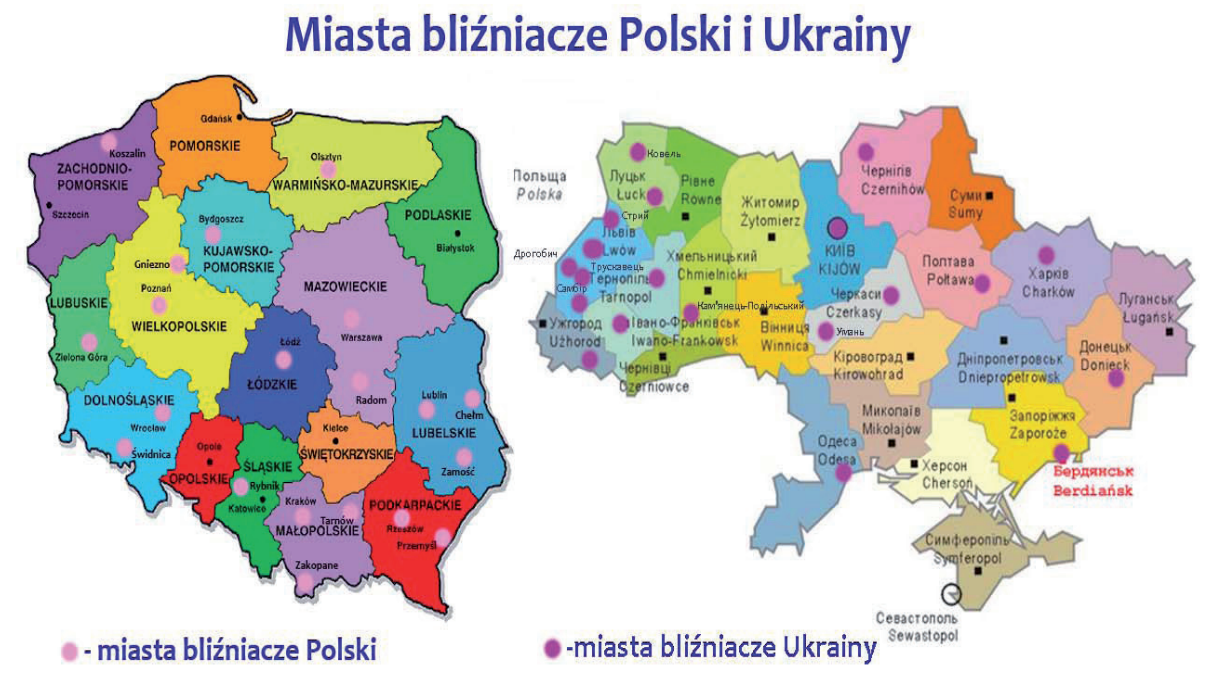

Źródło: opracowanie własne.

Ponadto Fundacja PAUCI wraz z partnerami realizuje bezpośrednio kilka programów, m.in.: Wprowadzanie europejskich standardów zarzadzania w administracji publicznej na Ukrainie, mający na celu reformę systemu doskonalenia zawodowego pracowników ukraińskiej służby cywilnej. Ten wieloletni projekt jest realizowany dzięki wsparciu brytyjskiego Global Opportunity Fund. Ważny także jest Program wymiany ekspertów, prowadzony przez PAUCI, który umożliwia wysoko wykwalifikowanym ekspertom polskim i ukraińskim dzielić się w praktyczny sposób swoimi doświadczeniami przez realizację konkretnych projektów. Program 
pozwala zarówno ekspertom z Polski pracować w ukraińskich organizacjach pozarządowych oraz instytucjach samorządowych, jak i organizować staże dla ekspertów ukraińskich w Polsce ${ }^{16}$.

\section{Wnioski}

Związki miast pokazują rosnącą aktywności społeczeństwa obywatelskiego. Kształtowanie współpracy partnerskiej i bliźniaczej między miastami Ukrainy i Polski odbyło się jeszcze za czasów radzieckich. Stosunki ukraińsko-polskie wykraczają poza granice współpracy dwustronnej, ponieważ łączy ich wspólna historia, kultura narodowa, stąd też łatwiej o zrozumienie i poszanowanie własnych interesów. Obecnie Ukraina ma najbardziej rozwiniętą sieć kontaktów międzyregionalnych z Polską. Praktycznie całe obwody Ukrainy i województwa Polski zawarły umowy o współpracy międzyregionalnej. Miasta każdego z 16 województw Polski mają związki partnerskie i bliźniacze z miastami w Ukrainie. Najwięcej ukraińskich partnerów mają województwa: podkarpackie, lubelskie, łódzkie, śląskie i mazowieckie. Z ukraińskiej strony najwięcej polskich partnerów posiadają regiony: odeski, iwanofrankowski, winnicki, wołyński, lwowski.

Miasta Ukrainy mają dużą liczbę miast bliźniaczych na całym świecie, lecz praktyczna strona tej współpracy jest na razie jeszcze mało efektywna. W tym kontekście doświadczenia Polski są niezwykle istotne. Uwzględniając to, że Polska jest jednym z największych partnerów Ukrainy na arenie międzynarodowej, ich analiza wydaje się celowa i uzasadniona w kontekście eurointegracyjnego kursu Ukrainy.

16 Фундація польсько-української співпраці PAUCI, http://www.pauci.org/ua/, odczyt z 25.04.2013. 